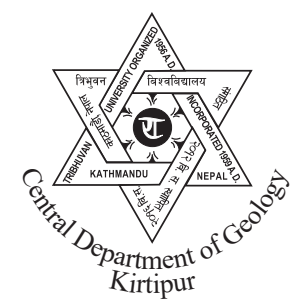

\title{
Dry season discharge and sediment yield of the northern tributaries of the Kathmandu Valley, Central Nepal
}

\author{
*Rajkumar Lama and Naresh Kazi Tamrakar \\ Central Department of Geology, Tribhuvan University, Kathmandu, Nepal
}

\begin{abstract}
Population growth, urbanization and improper land use practice cause change in natural behavior of the river system. In this point soil erosion and sediment deposition in the river channel adversely bring environmental problems like variation in discharge, surface water physical quality, sediment transportation capacity, sediment yield and stream power. In lack of proper research and planning, disasters like flooding, failure of engineering structure, bank erosion and imbalance in aquatic ecosystem can be seen. To better understand the stream, present work was carried out to determine the discharge, sediment transportation capacity, sediments yield and stream power of northern major tributaries of the Bagmati River. Subsequent to this, relations between the two or more than two morpho-hydraulic parameters with the discharge and sediments load were evaluated.

The northern Bagmati River basin occupies an area of 3750 sq. km and lies within 26042' and 27050' N latitude and 85002' and $85^{\circ} 58^{\prime}$ E longitude. The Bagmati River, non-glacial perennial river, consists of four main tributaries contributing from the northern part of the Bagmari River basin. They are the Manahara River, Bagmati River, Dhobi Khola and the Bishnumati River. The four major tributaries including the Bagmati River were upto sixth stream order. The study revealed that water discharge varied from 0.033 to $1.983 \mathrm{~m}^{3} / \mathrm{s}$ and the grain size distribution $\mathrm{d}_{50}$ ranged from 0.0002 to $0.0250 \mathrm{~m}$. The study found that the suspended load for dry season varied from 5.93 to $916 \mathrm{mg} / \mathrm{L}$ and the bed load from 6 to 393711 tonnes/day. The total sediment yield ranged from 0.58 to 22029.64 tonnes $/ \mathrm{km}^{2} /$ day. The boundary shear stress and critical shear stress ranged from 0.03 to $30.87 \mathrm{~N} / \mathrm{m}^{2}$ and 0.05 to $0.06 \mathrm{~N} / \mathrm{m}^{2}$, respectively. The stream power per unit channel width was found to vary from 0.001 to $0.06 \mathrm{KNm} / \mathrm{s} / \mathrm{m}^{2}$ for tributaries. Except at few sites, the rest of the sites of the studied river exhibit competency and good capability of sediment transport of the rivers. This study helps to implement proper engineering hydraulic practices around the river corridors.
\end{abstract}

Key words: Stream discharge, boundary shear stress, critical shear stress, sediment yield, stream power, Bagmati River

Accepted: 28 Aug, 2016

\section{INTRODUCTION}

River system is a natural and dynamic process which carries sediments generated due process of weathering, mass wasting and erosion of rocks and soils present in the nature. In this point, on the basis of the characteristics of the river system, particular system of the river has its own capacity of transporting sediment and yielding sediment from the river basin. The sediment yield and the amount of sediment load depend

\footnotetext{
*Corresponding author:

E-mail address: rajlamaghising2016@gmail.com
}

upon hydraulic regime, geological setting, land use and human influences. When sediment load increases due to high erosion rate than sediment yield rate, the normal range exceeds resulting problems to mankind and manmade structures, and reduce environmental quality and elements of rivers. Therefore, to overcome such situations it is important to study estimation of sediment yield and sediment transport capacity of the rivers. According to Tamrakar and Shrestha (2008) rivers in the Lesser Himalaya are capable to flush out sediment compared to such in the Siwaliks because of unstable slope. Various studies have shown that the rivers in the 
northern Kathmandu Valley are far from the equilibrium and there existed various bank erosion problems (Tamrakar, 2004a, 2004b; Shrestha and Tamrakar, 2007a, 2007b; Tamrakar et al., 2011). Guzman et al. (2013) displayed the suspended sediment concentration-discharge relationships in which concentration of suspended sediment is high for low flow and sediment concentration is low for high flow. Wolman and Miller (1960) proposed that the amount of sediment transported by flows of a given magnitude depends on the form of the relationship between discharge and sediment load and on the frequency distribution of the discharge events. Ashmore and Day (1988) studied drainage areas ranging from 10 to over $100,000 \mathrm{~km}^{2}$ and for the duration between 5 and 29 years, and found that the effective discharge was less than $0.1 \%$ in some cases and over $15 \%$ in others, with the majority of stations having values between 1 and $10 \%$. Similarly, Powell et al. (1996) studied the bed load contribution and represented a mean annual bed load yield of 39 tonnes $\mathrm{km}^{-2}$ year-1. Although bed load contributed up to $13 \%$ of the sediment load during individual events, on average it constituted only $8 \%$ of the total sediment yield of 472 tonnes $\mathrm{km}^{-2}$ year-1.

This study aims to provide piece of information on sediment transport, stream competency, stream power, and sediment yield across northern main tributaries of the Bagmati River basin. Data acquired after analysis help to improve understanding of sediment transport relations, provide information for designing stream restoration, and flood mitigation. Different transects

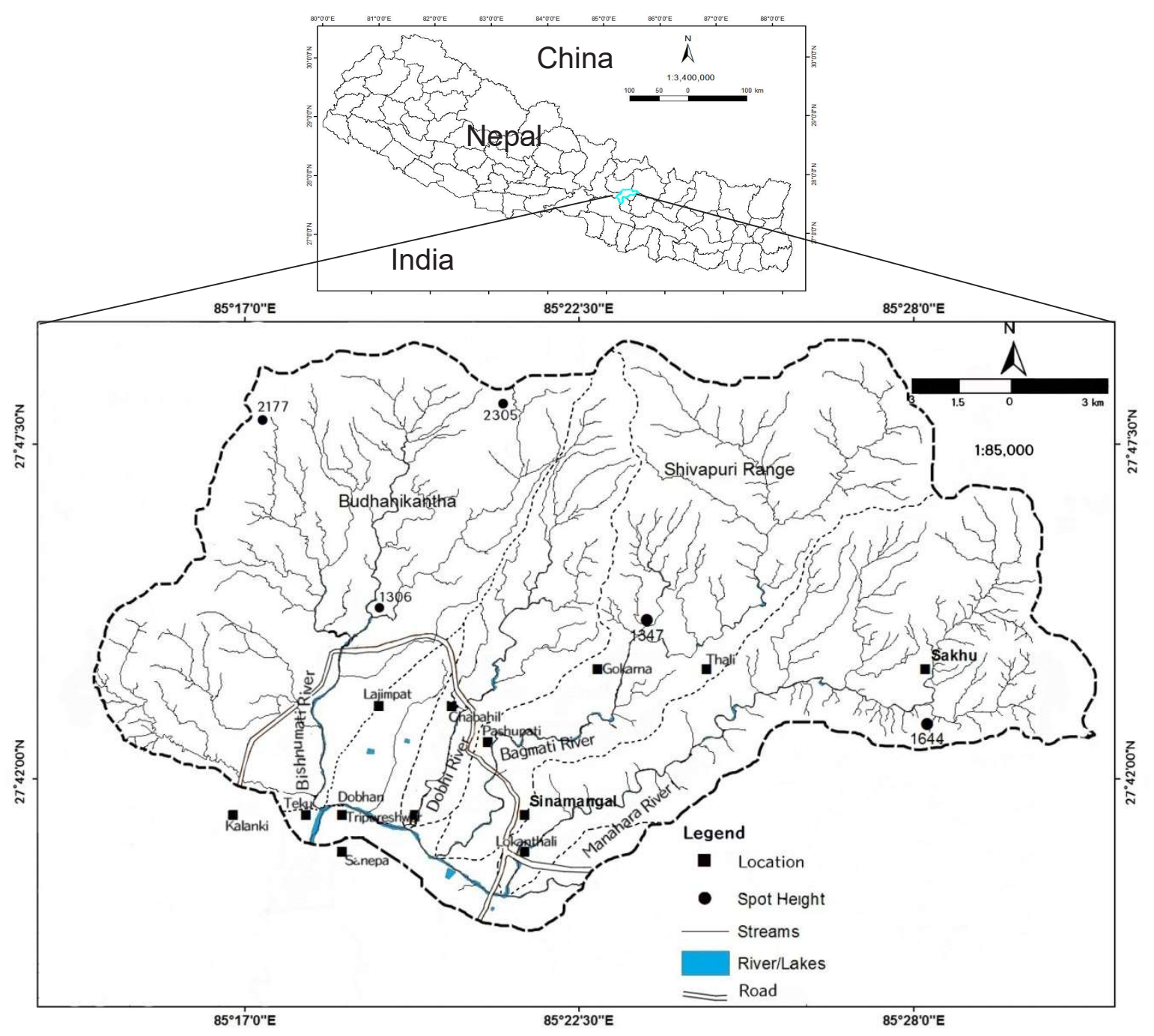

Fig. 1 Location and drainage map of the study area. 
(ten in each) were selected at main tributaries of the Bagmati River basin (Fig. 1) for dry season only to examine suspended sediment concentration, sediment loads, particle size distribution, stream power and sediment yield for particular season.

Geologically, the Kathmandu Valley basin comprises fluvio-lacustrine sediments which overlies the basement rocks of Pre-Cambrian to Devonian age (Table 1). The basement rocks mainly consist of phyllite, sandstone, slate, meta-sandstones, quartzite, siltstone, shale and crystalline limestone in the east, west and the south of the valley. Similarly, in the north and the northeast, basement rocks comprise gneiss, schist and granite (Stöcklin and Bhattarai, 1977; Stöcklin, 1980).

Furthermore, the basin fill sediments are divided into two series; they are Quaternary Unconsolidated Sediments and Plio-Pliestocene slightly consolidated sediment (DMG, 1998) as shown in Fig. 2. Present study was conducted on the northern part of the Bagmati River basin, located in the Kathmandu Valley. The watershed occupies 99.34 sq. $\mathrm{km}$ area including partly the, Lalitpur and Bhaktapur Districts. The latitude and longitude of the watershed is $74^{0} 53^{\prime}$ to $74^{0} 75^{\prime} \mathrm{N}$ and

Table 1: Geology of the study (a) Stratigraphic column of the Kathmandu Complex (Stöcklin, 1980), and (b) Stratigraphic column of the basin-fill sediments (after Yoshida and lgarashi, 1984).

Table 1(a)

\begin{tabular}{|c|c|c|c|}
\hline Stratigraphic unit & Composition & Distribution & Age \\
\hline Recent Flood Plain & Sand, silt and clay & Along the Bagmati River and its tributaries & Holocene \\
\hline Lower Terrace deposits & Micaceous sand and gravel & Along the Bagmati River and its tributaries & \\
\hline Patan Formation & $\begin{array}{l}\text { Laminated arkosic sand, silt } \\
\text { clay and peat layers }\end{array}$ & Mainly around Patan and Kathmandu cities & Pleistocene \\
\hline Thimi Formation & $\begin{array}{l}\text { Arkosic sand, silt clay, peat } \\
\text { and gravel }\end{array}$ & $\begin{array}{l}\text { Around Kathmandu at Pashupati, Airport, } \\
\text { Thimi and Bhaktapur }\end{array}$ & \\
\hline Gokarna Formation & $\begin{array}{l}\text { Laminated arkosic sand, silt, } \\
\text { clay and peat }\end{array}$ & $\begin{array}{l}\text { North part of the Kathmandu Valley } \\
\text { around the Gokarna area }\end{array}$ & \\
\hline Boregaon Terrace Deposit & $\begin{array}{l}\text { Rounded gravel with } \\
\text { laminated silt and sand }\end{array}$ & $\begin{array}{l}\text { Southern area of the Kathmandu Valley near } \\
\text { the Chapagaon and the Boregaon Villages }\end{array}$ & \\
\hline Chapagaon Terrace Deposit & $\begin{array}{l}\text { Subrounded gravel of phyllite } \\
\text { and metasandstone }\end{array}$ & $\begin{array}{l}\text { Southern area of the Kathmandu Valley near } \\
\text { the Chapagaon Village }\end{array}$ & \\
\hline Pyangaon Terrace Deposit & $\begin{array}{l}\text { Sub rounded gravel of meta- } \\
\text { sandstone and phyllite }\end{array}$ & $\begin{array}{l}\text { Southern areas of the Kathmandu Valley } \\
\text { near the Pyangaon and the Godavari }\end{array}$ & Village \\
\hline Lukundol Formation & $\begin{array}{l}\text { Weakly consolidated clay, silt } \\
\text { and beds with lignite layers }\end{array}$ & $\begin{array}{l}\text { Along terrace, scarps near the Chapagaon } \\
\text { Village, probabably widely distributed in } \\
\text { the subsurface of the Kathmandu Valley }\end{array}$ & Pliocene \\
\hline
\end{tabular}

Table 1(b)

\begin{tabular}{|c|c|c|c|c|c|}
\hline Complex & Group & Formation & Main Lithology & Thickness (m) & Age \\
\hline \multirow{9}{*}{ 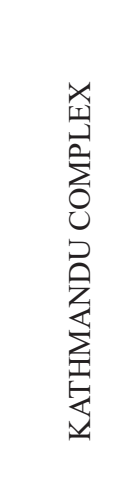 } & \multirow{5}{*}{ 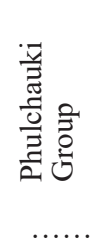 } & Godavari Formation & Limestone, Dolomite & 300 & Devonian \\
\hline & & Chitlang Formation & Slate & 1000 & Silurian \\
\hline & & Chandragiri Formation & Limestone & 2000 & Ordovician \\
\hline & & Sopyang Formation & Slate, Calcareous Phyllite & 200 & Cambrian? \\
\hline & & 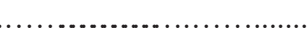 & ....Transitional Zone & ……․ $\quad \cdots$ & ........ \\
\hline & \multirow{4}{*}{ 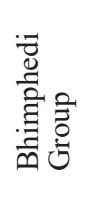 } & Tistung Formation & Metasandstone, Phyllite, Schist & 3000 & Late Paleozoic \\
\hline & & Markhu Formation & Marble, Schist & 1000 & Precambrian \\
\hline & & Kulekhani Formation & Quartzite, Schist & 2000 & Precambrian \\
\hline & & Chisapani Quartzite & White Quartzite & 400 & Precambrian \\
\hline
\end{tabular}




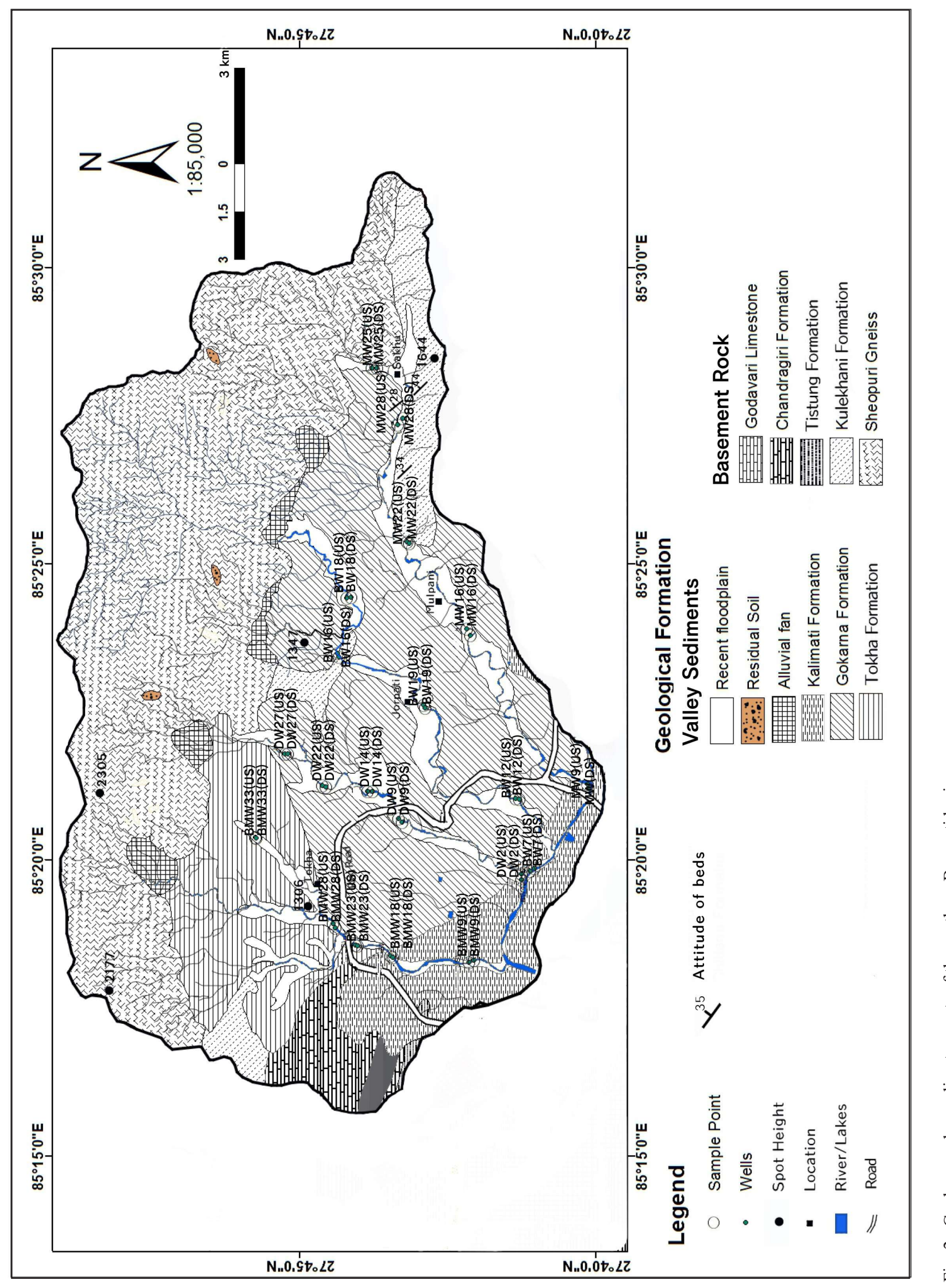


$21^{0} 54^{\prime}$ to $21^{0} 62^{\prime} \mathrm{E}$. The temperature of this area varied from $9^{0} \mathrm{C}$ to $48^{\circ} \mathrm{CE}$. The watershed received $552 \mathrm{~mm}$ average rainfall per year.

\section{METHODOLOGY}

\section{Stream discharge calculations}

During the study, the stream discharge of four rivers; the Bishnumati River, the Dhobi Khola, the Bagmati River, and the Manahara River were calculated for different ten transect of each river. The area-velocity method was used to calculated cross-sectional area and velocity. Velocity was recorded by using a current meter. Discharge $(\mathrm{Q})$ was the volume of water flowing through a stream channel cross-section per unit time (Chow, 1986). Discharge was calculated using the continuity equation:

$$
\mathrm{Q}=\mathrm{VA} \text {. }
$$

Where, $\mathrm{V}=$ Velocity of stream flow $(\mathrm{m} / \mathrm{s}), \mathrm{A}=$ crosssectional area $\left(\mathrm{m}^{2}\right), \quad \mathrm{Q}=$ Discharge $\left(\mathrm{m}^{3 / \mathrm{s}}\right)$.

\section{Slope (s)}

Slope of the stream was the ratio of elevation difference to distance of river. Although slope is partly imposed by geological constraints, rivers are nevertheless free to change slope substantially by means of aggradation and degradation. Data from topographic maps were used to calculate slope here.

\section{Suspended sediment concentration (SSC)}

Measurement of suspended sediment was done by using a filtration method (ASTM D3977-97, 2002). This is simple, laboratory analytical method to estimate suspended solid which quantifies concentrations of suspended solid material in the surface water. SCC data were obtained by measuring the dry weight of all the sediment from known volume of water-sediment mixture collected from depth integrated sampling of water from stream cross-sections. Usually, SSC is expressed in $(\mathrm{mg} / \mathrm{L})$.

\section{Bed load and suspended load calculation}

Bed load is defined as part of sediment within the bed layer moved by saltation (jumping), rolling, or sliding. It is the clastic material that moves through the channel fully supported by the channel bed itself. These materials are mainly sand and gravels which are kept in motion by the shear stress acting at the boundary. The diameter of bed and bar substrate is routinely measured using some variation of the Wolman pebble count method (Wolman, 1954). Pebble counts involve measuring the B-or intermediate axis of 100 to 400 individual bed particles collected from the channel bed by hand using some type of ruler or template (Bunte and Abt, 2001). Typically, pebble diameter measurements were made in millimeters. Bed substrate classes generally followed those in Rosgen (1994).

For the bed load calculation, slope and stream sediment characters were assessed to characterize grain size of each of segments in the reach-scale and in the cross-section scale, Wolman's (1954) pebble counting was adopted in numbers of transects including pools during the cross-section survey. The particle size distribution was used to obtain the $\mathrm{d}_{50}$.

The Hassanzadeh (2007) bedload equation which agrees closely with the measured data is expressed as follows:

$$
\begin{array}{r}
\left\{\mathrm{q}_{\mathrm{b}} /\left(\mathrm{agd}^{3}\right)^{0.5}\right\}=24 \mathrm{f}^{2.5} . \\
\mathrm{f}=\tau_{0} /\left(\gamma_{\mathrm{S}}-\gamma\right) \mathrm{d} .
\end{array}
$$

and

$$
\mathrm{a}=\left(\gamma_{\mathrm{S}}-\gamma\right) / \gamma
$$

where, $q_{b}=$ bed load in $\left(\mathrm{m}^{2} / \mathrm{s}\right), g=$ acceleration due to gravity, $\mathrm{d}=$ median grain diameter $\left(\mathrm{d}_{50}\right), \mathrm{f}=$ hydrodynamic-immersed gravity force ratio, $\tau_{0}=$ boundary shear stress $=\gamma \mathrm{R}_{\mathrm{h}} \mathrm{S}, \mathrm{Rh}=$ hydraulic radius, $\mathrm{S}=$ stream slope, $\mathrm{a}=$ immersed sediment specific gravity, $\gamma_{\mathrm{S}}=$ specific weight of sediment $=2650 \mathrm{~kg} / \mathrm{m}^{3}$, $\gamma=$ specific weight of water $=1000 \mathrm{~kg} / \mathrm{m}^{3}$ (which may be varied depending on water temperature), and $\gamma_{\mathrm{s}}-\gamma=$ submerged specific weight of sediment, $\mathrm{kg} / \mathrm{m}^{3}$.

Bed load in the present study was estimated using Hasanzadeh's (2007) empirical equation. Then the bed load transport capacity $\left(\mathrm{Q}_{\mathrm{b}}\right)$ in $\mathrm{kg} / \mathrm{s}$ was calculated using the following relation:

$$
\mathrm{Q}_{\mathrm{b}}(\mathrm{kg} / \mathrm{s})=\rho_{\mathrm{s}} \mathrm{W} \mathrm{q}_{\mathrm{b}} \text {. }
$$

The bed load transport capacity $(\mathrm{Qb})$ in $\mathrm{kg} / \mathrm{s}$ was then converted into the tonnes/day using the following 
expression:

$$
\mathrm{Q}_{\mathrm{b}}\left(\text { tonnes/day) }=\rho_{\mathrm{S}} \mathrm{W} \mathrm{q_{ \textrm {b } }}\right. \text {. 86.4...(6) }
$$

Where, conversion factor is $86.4, \mathrm{~W}$ is width of channel, and $\mathrm{q}_{\mathrm{b}}$ is bed load in $\mathrm{m}^{2} / \mathrm{s}$.

\section{Shear stress}

It is related to sediment mobilization and transport in many theoretical and empirical treatments of sediment transport. Following relation wass used to obtain boundary shear stress (Shields, 1936):

$$
\tau=\gamma \mathrm{RS}
$$

Critical shear stress $\left(\tau_{c}\right)$ for $d_{50}$ were calculated using following relation

$$
\tau_{\mathrm{c}}=\theta_{\mathrm{c}} \cdot \mathrm{g}\left(\rho_{\mathrm{c}}-\rho\right) * \mathrm{~d}_{50}
$$

where, $\tau=$ boundary shear stress, $\left(\mathrm{N} / \mathrm{m}^{2}\right), \gamma=$ specific weight of water $\left(\mathrm{N} / \mathrm{m}^{3}\right), \mathrm{R}=$ Hydraulic radius $(\mathrm{m}), \mathrm{S}=$ Average stream slope $(\mathrm{m} / \mathrm{m}), \theta_{\mathrm{c}}=$ Shields parameter for critical dimensionless shear stress was taken from the Shields curve, $g$ = gravitational constant, $\mathrm{d}_{50}=$ median diameter of particles, $\rho_{\mathrm{c}}=$ density of sediments, $\rho=$ density of water.

\section{Stream power}

Bagnold (1966) defined stream power concept as the available power supply, or time rate of energy supply, to unit length of a stream is clearly the time rate of liberation in kinetic form of the liquids potential energy as it descends the gravity slope. The available stream power supply can be expressed as:

$$
\Omega=\gamma \mathrm{QS} \text {. }
$$

Where, $\Omega=$ stream power $(\mathrm{KN} / \mathrm{s} / \mathrm{m}), \gamma=$ unit weight of water $\left(\mathrm{KN} / \mathrm{m}^{3}\right), \mathrm{Q}=$ hydraulic discharge of the stream $\left(\mathrm{m}^{3} / \mathrm{s}\right)$, and $\mathrm{S}=$ stream slope $(\mathrm{m} / \mathrm{m})$.

Stream power per unit of bed area (Bagnold, 1966) was calculated using the following relation:

$$
\omega=\tau_{\mathrm{b}} \mathrm{V}
$$

\section{RESULTS AND DISSCUSION}

\section{Stream order and profile}

The Bishnumati river, one of major tributary of Bagmati River from the northern valley, is a sixth order stream that has $16.344 \mathrm{~km}$ length and the total watershed area of $102.26 \mathrm{sq}$. km. The Manahara River is a fifth order river having major contribution for the Bagmati has length of $25.24 \mathrm{~km}$ and watershed area of 74.26 sq. km (Fig. 3). The Dhobi Khola is a fifth Order River which has minor contribution for the Bagmati Basin, and has length of $17.81 \mathrm{~km}$ and watershed area of 30.74 sq. km. Similarly, the Bagmati River is a sixth order, before the mixing with another major tributary, and has $26.94 \mathrm{~km}$ length (Fig. 3) and catchment area of 74.13 sq. $\mathrm{km}$ in the northern territory of the Kathmandu Valley.

\section{Morpho-hydraulic parameters}

The calculated hydraulic parameters values vary from upstream to downstream in each stream (Table 2). Slope $(\mathrm{m} / \mathrm{m})$ is $0.002-0.240,0.001-0.020,0.001-0.027$ and 0.001-0.035 in the Manahara River (maximum), the Bagmati River (minimum), the Dhobi Khola and the Bishnumati River, respectively. Entire values randomly changed in each sampling point of individual river. W/D ratio is maximum at the Bagmati River with 16.60-163.04, minimum at the Bishnumati River with 8.21-34.04 followed by the Manahara River i.e. 17.05-57.97 and 9.39-153.47 in the Dhobi Khola. Hydraulic radius ranges are $0.07-0.28 \mathrm{~m}, 0.12-0.30 \mathrm{~m}$, $0.03-0.17 \mathrm{~m}$ and $0.09-0.63 \mathrm{~m}$ in the Manahara River, the Bagmati River, Dhobi Khola and the Bishnumati River, respectively.

The result shows that variation is large for the Bishnumati River and low for the Dhobi Khola. The hydraulic radius is increasing towards downstream of all streams with slight fluctuation but in the sampling points like DW2(DS) and BMW9(DS) values suddenly decrease, which can be due to anthropogenic activities near dense settlement areas. Velocities of the individual stream are $0.27-0.63 \mathrm{~m} / \mathrm{s}, 0.12-0.50 \mathrm{~m} / \mathrm{s}, 0.18-0.46 \mathrm{~m} / \mathrm{s}$ and $0.19-0.62 \mathrm{~m} / \mathrm{s}$ in the Manahara River, the Bagmati River, the Dhobi Khola and the Bishnumati River, respectively. Discharge ranged between 0.06-0.717 $\mathrm{m} 3 / \mathrm{s}$ in the Manahara River which is minimum discharge recorded compared to other studied rivers. Discharge of surface water measured in the Bagmati River $\left(0.294-1.983 \mathrm{~m}^{3} / \mathrm{s}\right)$ is maximum discharge during dry period among four rivers studied. Discharge of Dhobi Khola $\left(0.033-1.974 \mathrm{~m}^{3} / \mathrm{s}\right)$ is nearly equal to that of the Bagmati River, however in the initial point of 


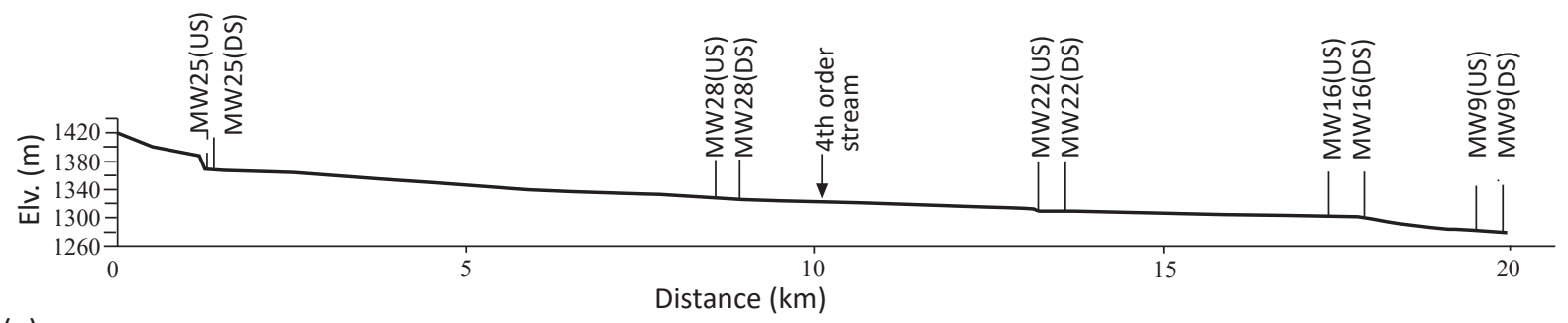

(a)
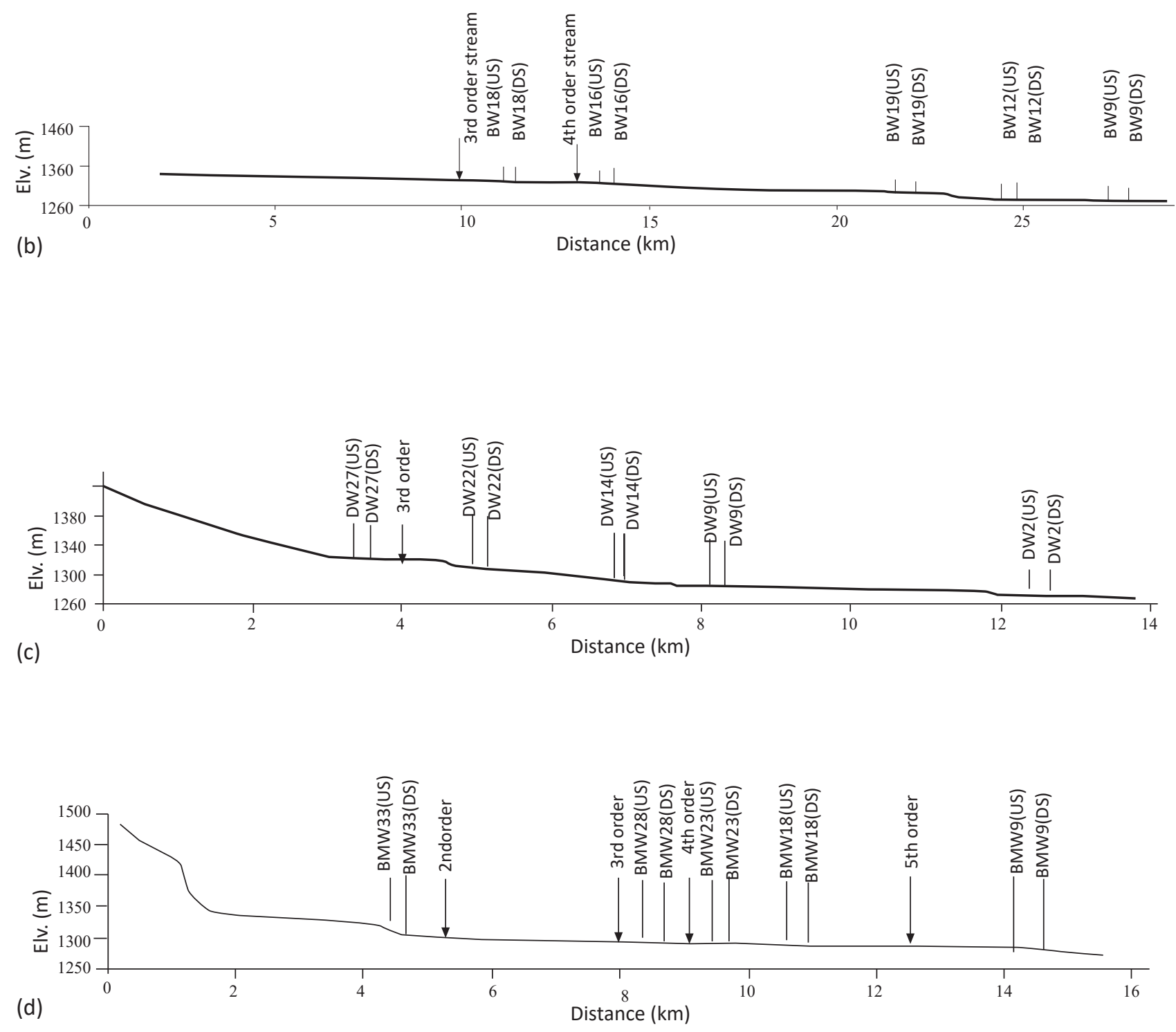

Fig. 3 Longitudinal profies of rivers. (a) Manahara River, (b) Bagmati River, (c) Dhobi Khola and (d) Bishnumati River 
Table 2: Morpho-hydraulic parameters of different rivers.

\begin{tabular}{|c|c|c|c|c|c|c|c|c|c|c|c|}
\hline River & Location & $\begin{array}{c}\text { Distance } \\
(\mathrm{km})\end{array}$ & $\begin{array}{l}\text { Slope } \\
(\mathrm{m} / \mathrm{m})\end{array}$ & Width (m) & Area $\left(\mathrm{m}^{2}\right)$ & Depth (m) & $\mathrm{W} / \mathrm{D}$ & WP (m) & $\mathrm{R}_{\mathrm{h}}(\mathrm{m})$ & $\mathrm{V}(\mathrm{m} / \mathrm{s})$ & $\mathrm{Q}\left(\mathrm{m}^{3} / \mathrm{s}\right)$ \\
\hline \multirow{10}{*}{ 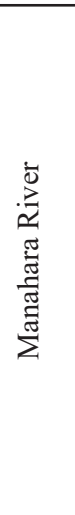 } & MW25(US) & 1.20 & 0.022 & 2.30 & 0.18 & 0.08 & 29.39 & 2.46 & 0.07 & 0.32 & 0.060 \\
\hline & MW25(DS) & 1.30 & 0.240 & 2.50 & 0.23 & 0.09 & 27.17 & 2.68 & 0.09 & 0.30 & 0.059 \\
\hline & MW28(US) & 8.54 & 0.003 & 5.30 & 0.74 & 0.14 & 37.86 & 5.58 & 0.13 & 0.27 & 0.193 \\
\hline & MW28(DS) & 8.61 & 0.040 & 5.50 & 0.54 & 0.10 & 56.12 & 5.70 & 0.09 & 0.36 & 0.204 \\
\hline & MW22(US) & 13.16 & 0.004 & 8.00 & 1.10 & 0.14 & 57.97 & 8.28 & 0.13 & 0.63 & 0.711 \\
\hline & MW22(DS) & 13.23 & 0.043 & 7.40 & 1.29 & 0.17 & 42.52 & 7.75 & 0.17 & 0.35 & 0.443 \\
\hline & MW16(US) & 17.69 & 0.002 & 6.00 & 1.03 & 0.17 & 34.95 & 6.34 & 0.16 & 0.27 & 0.286 \\
\hline & MW16(DS) & 17.76 & 0.013 & 5.60 & 0.90 & 0.16 & 34.84 & 5.92 & 0.15 & 0.30 & 0.293 \\
\hline & MW9(US) & 19.71 & 0.008 & 5.10 & 0.89 & 0.17 & 29.22 & 5.45 & 0.16 & 0.48 & 0.481 \\
\hline & MW9(DS) & 19.74 & 0.033 & 5.40 & 1.71 & 0.32 & 17.05 & 6.03 & 0.28 & 0.41 & 0.717 \\
\hline \multirow{10}{*}{ 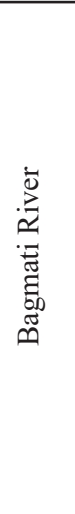 } & BW18(US) & 4.53 & 0.002 & 8.00 & 1.03 & 0.13 & 62.14 & 8.26 & 0.12 & 0.33 & 0.386 \\
\hline & BW18(DS) & 4.59 & 0.010 & 6.50 & 2.16 & 0.33 & 19.56 & 7.16 & 0.30 & 0.12 & 0.294 \\
\hline & BW16(US) & 8.33 & 0.001 & 6.00 & 1.58 & 0.26 & 22.78 & 6.53 & 0.24 & 0.37 & 0.628 \\
\hline & BW16(DS) & 8.40 & 0.008 & 5.30 & 1.13 & 0.21 & 24.86 & 5.73 & 0.20 & 0.43 & 0.571 \\
\hline & BW19(US) & 9.50 & 0.002 & 10.10 & 1.48 & 0.15 & 68.93 & 10.39 & 0.14 & 0.22 & 0.422 \\
\hline & BW19(DS) & 9.58 & 0.020 & 4.50 & 1.22 & 0.27 & 16.60 & 5.04 & 0.24 & 0.32 & 0.473 \\
\hline & BW12(US) & 10.65 & 0.004 & 12.00 & 2.44 & 0.20 & 59.02 & 12.41 & 0.20 & 0.30 & 0.756 \\
\hline & BW12(DS) & 10.68 & 0.013 & 10.50 & 2.06 & 0.20 & 53.52 & 10.89 & 0.19 & 0.50 & 1.076 \\
\hline & BW7(US) & 14.15 & 0.001 & 24.00 & 6.00 & 0.25 & 96.00 & 24.50 & 0.24 & 0.28 & 1.703 \\
\hline & BW7(DS) & 14.21 & 0.008 & 30.00 & 5.52 & 0.18 & 163.04 & 30.37 & 0.18 & 0.33 & 1.983 \\
\hline \multirow{10}{*}{$\begin{array}{l}\frac{\pi}{0} \\
\overrightarrow{0} \\
0 \\
0 \\
0 \\
\overline{0}\end{array}$} & DW27(US) & 3.03 & 0.023 & 1.10 & 0.09 & 0.08 & 13.44 & 1.26 & 0.07 & 0.34 & 0.033 \\
\hline & DW27(DS) & 3.12 & 0.011 & 1.30 & 0.18 & 0.14 & 9.39 & 1.58 & 0.11 & 0.32 & 0.062 \\
\hline & DW22(US) & 4.61 & 0.008 & 2.20 & 0.36 & 0.16 & 13.44 & 2.53 & 0.14 & 0.23 & 0.085 \\
\hline & DW22(DS) & 4.72 & 0.027 & 2.60 & 0.32 & 0.12 & 21.13 & 2.85 & 0.11 & 0.25 & 0.087 \\
\hline & DW14(US) & 6.34 & 0.015 & 2.20 & 0.37 & 0.17 & 13.08 & 2.54 & 0.15 & 0.18 & 0.086 \\
\hline & DW14(DS) & 6.45 & 0.009 & 2.30 & 0.27 & 0.12 & 19.59 & 2.53 & 0.11 & 0.43 & 0.116 \\
\hline & DW9(US) & 7.59 & 0.005 & 6.50 & 0.98 & 0.15 & 43.11 & 6.80 & 0.14 & 0.28 & 0.292 \\
\hline & DW9(DS) & 7.69 & 0.020 & 5.40 & 0.19 & 0.04 & 153.47 & 5.47 & 0.03 & 0.27 & 0.245 \\
\hline & DW2(US) & 11.75 & 0.001 & 13.00 & 2.29 & 0.18 & 73.80 & 13.35 & 0.17 & 0.53 & 1.458 \\
\hline & DW2(DS) & 11.9 & 0.027 & 8.00 & 1.44 & 0.18 & 44.44 & 8.36 & 0.17 & 0.46 & 1.974 \\
\hline \multirow{10}{*}{ 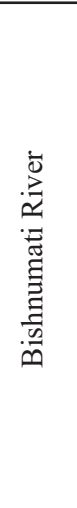 } & BMW33(US) & 11.13 & 0.018 & 3.20 & 0.30 & 0.09 & 34.04 & 3.39 & 0.09 & 0.30 & 0.104 \\
\hline & BMW33(DS) & 11.23 & 0.035 & 4.00 & 0.50 & 0.13 & 31.75 & 4.25 & 0.12 & 0.23 & 0.116 \\
\hline & BMW28(US) & 13.58 & 0.003 & 5.50 & 1.30 & 0.24 & 23.31 & 5.97 & 0.22 & 0.25 & 0.359 \\
\hline & BMW28(DS) & 13.70 & 0.013 & 5.20 & 1.99 & 0.38 & 13.61 & 5.96 & 0.33 & 0.19 & 0.376 \\
\hline & BMW23(US) & 21.23 & 0.001 & 7.20 & 1.66 & 0.23 & 31.30 & 7.66 & 0.22 & 0.30 & 0.522 \\
\hline & BMW23(DS) & 21.33 & 0.013 & 5.00 & 0.98 & 0.20 & 25.51 & 5.39 & 0.18 & 0.47 & 0.507 \\
\hline & BMW18(US) & 24.05 & 0.001 & 6.00 & 2.42 & 0.40 & 14.85 & 6.81 & 0.36 & 0.36 & 1.007 \\
\hline & BMW18(DS) & 24.20 & 0.001 & 5.40 & 3.19 & 0.59 & 9.16 & 6.58 & 0.48 & 0.24 & 0.932 \\
\hline & BMW9(US) & 26.68 & 0.001 & 6.40 & 4.99 & 0.78 & 8.21 & 7.96 & 0.63 & 0.33 & 1.715 \\
\hline & BMW9(DS) & 26.80 & 0.008 & 4.80 & 1.75 & 0.36 & 13.17 & 5.53 & 0.32 & 0.62 & 1.256 \\
\hline
\end{tabular}


stream of both rivers, values have wide difference. Lastly, discharge calculated at the Bishnumati River is $0.104-1.256 \mathrm{~m}^{3} / \mathrm{s}$, which gradually diminishes towards downstream, perhaps due to human influence such as river training activities, channel improvement work, and due to loss through substrates.

\section{Grain size analysis}

To calculated median grain size $\left(\mathrm{d}_{50}\right)$, Wolman Pebble counting method was adopted and graphical method was used. On the basis of grain size, streams are classified into sand bed and gravel bed with value ranged from $0.0001 \mathrm{~m}$ to $0.0008 \mathrm{~m}$ and $0.01 \mathrm{~m}$ to 0.2 $\mathrm{m}$, respectively. The $\mathrm{d}_{50}$ at the Manahara River, the Bagmati River, the Dhobi Khola and the Bishnumati River varies from $0.0007 \mathrm{~m}$ to $0.025 \mathrm{~m}, 0.0002 \mathrm{~m}$ to $0.02 \mathrm{~m}, 0.0002 \mathrm{~m}$ to $0.013 \mathrm{~m}$ and $0.0002 \mathrm{~m}$ to $0.004 \mathrm{~m}$, respectively. The range of $\mathrm{d}_{50}$ is similar in the Bagmati River and the Dhobi Khola but in the Manahara River and the Bishnumati River, it is quite different. Generally, grain size becomes finer towards downstream during normal runoff period of the stream. But, the trend line of the Dhobi Khola is increasing towards downstream of the river. This can be due to change in streambed sediment brought about by the river training s during study time. Since, all the range is in between $0.01 \mathrm{~m}$ to $0.2 \mathrm{~m}$, all streams are gravel bed stream.

\section{Suspended load and transport capacity}

Sediment load in the main tributaries at the northern part of the Kathmandu Valley was calculated by multiplying the main suspended sediment concentration (SSC) in water at each cross-section by average discharge in the same cross-section. SSCs on the Manahara River, the Bagmati River, the Dhobi Khola and the Bishnumati River ranged from 12 to $588 \mathrm{mg} / \mathrm{L}$, 21 to $163 \mathrm{mg} / \mathrm{L}, 82$ to $600 \mathrm{mg} / \mathrm{L}$, and 44 to $916 \mathrm{mg} / \mathrm{L}$, respectively (Table 3). Among all streams, the Bishnumati River contributed maximum amount of SSC whereas the Dhobi Khola contributed minimum SSC. The sediment rating curve i.e., discharge versus suspended sediment concentration shows that negative correlation in the Bagmati River and the Dhobi Khola but anomalous result can be seen at DW22(US) of the Dhobi Khola. Similarly, at studied transects like MW22 (US and DS) and BW16(DS) and BW19(US), values increased exceptionally in the Manahara River and decrease in the Bagmati River. But the positive correlation could be seen in both streams. Anomalous results at individual transect could be resulted due to human influence near river channel; agriculture practice, deforestation etc.

\section{Bed load and transport capacity}

The calculation of rate of bed load was done using the Hassanzadeh (2007) type of common dimensionless formulas on the hydraulics of sediment transport. The existing relations were used to determine the rate of bedload in volume per unit time and unit width (qs) and rate of bedload in weight per unit time $\left(\mathrm{Q}_{\mathrm{b}}\right)$. The rate of bed load transport $\left(\mathrm{Q}_{\mathrm{s}}\right)$ has though increased (Fig. 4) from upstream portion of all major northern tributaries of the Bagmati River towards the downstream portion, the trend is fluctuating.

Bed load transport at the Manahara River is minimum (6 tonnes/day) at MW28(US) and maximum (393711 tonnes/day) at MW9(DS). At the Bagmati River it is minimum (15 tonnes/day) at BW18(US) and maximum (43124 tonnes/day) at BW19(DS). Similarly, at the Dhobi Khola it is minimum (6 tonnes/day) at DW2(US) and maximum (44071 tonnes/day) at DW22(DS). In the Bishnumati River, the minimum bedload is 23 tonnes/day at BMW9(US) and maximum is 40203 tonnes/day at BMW28(DS).

\section{Total sediment yield}

Total Sediment Yield (tonnes $/ \mathrm{km}^{2} /$ day) at the Manahara River ranged from 0.53 Tonnes $/ \mathrm{km}^{2} /$ day (MW28(US)) to 22029.64 tonnes $/ \mathrm{km}^{2} /$ day (MW25(DS)) (Table 3). At the Bagmati River it ranged from 0.59 tonnes $/ \mathrm{km}^{2} /$ day (BW18(US)) to 710.70 tonnes $/ \mathrm{km}^{2} /$ day (BW19(DS)). At the Dhobi Khola the total sediment yield varies between 0.70 tonnes $/ \mathrm{km}^{2} /$ day (at DW2 (US)) and 2493.22 tonnes $/ \mathrm{km}^{2} /$ day (at DW22(DS)). Likewise, total sediment yield varied from 0.58 tonnes $/ \mathrm{km}^{2} /$ day (at BMW9(US)) to 227.01 tonnes $/ \mathrm{km}^{2} / \mathrm{day}$ (at BMW33(DS)).

\section{Stream power}

Stream power $(\omega)$ is a measurement of the energy transfer (Bagnold, 1966) and is a stream power per unit 
R. Lama and N. K. Tamrakar/ Bulletin of the Department of Geology, vol. 19, 2016, pp. 29-44

Table 3: Total sediment yield from different transects

\begin{tabular}{|c|c|c|c|c|c|c|c|}
\hline River & Location & $\begin{array}{c}\text { Distance } \\
(\mathrm{km})\end{array}$ & $\begin{array}{c}\text { Suspended } \\
\text { Load, SSD } \\
\text { (Tonnes/day) }\end{array}$ & $\begin{array}{r}\text { Bedload, } \mathrm{Q}_{\mathrm{b}} \\
\text { (Tonnes/day) }\end{array}$ & $\begin{array}{c}\text { Total load } \\
\text { (Tonnes/day) }\end{array}$ & $\begin{array}{c}\text { Basin area } \\
\text { contributing } \\
\text { to site }\left(\mathrm{km}^{2}\right)\end{array}$ & $\begin{array}{c}\text { Total SY } \\
\text { (Tonnes } / \mathrm{km}^{2} / \text { day) }\end{array}$ \\
\hline \multirow{10}{*}{ 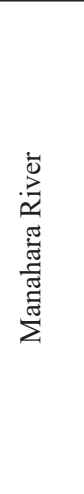 } & MW25(US) & 1.20 & 27.36 & 123 & 150 & 7.10 & 21.16 \\
\hline & MW25(DS) & 1.30 & 17.57 & 178423 & 178440 & 8.10 & 22029.64 \\
\hline & MW28(US) & 8.54 & 8.06 & 6 & 15 & 27.33 & 0.53 \\
\hline & MW28(DS) & 8.61 & 5.93 & 1420 & 1426 & 27.86 & 51.20 \\
\hline & MW22(US) & 13.16 & 66.23 & 15 & 81 & 52.20 & 1.55 \\
\hline & MW22(DS) & 13.23 & 114.68 & 232219 & 232334 & 52.48 & 4427.10 \\
\hline & MW16(US) & 17.69 & 7.85 & 30 & 38 & 59.28 & 0.64 \\
\hline & MW16(DS) & 17.76 & 18.58 & 7584 & 7602 & 59.61 & 127.53 \\
\hline & MW9(US) & 19.71 & 9.70 & 103 & 113 & 73.79 & 1.53 \\
\hline & MW9(DS) & 19.74 & 14.82 & 393711 & 393726 & 74.23 & 5304.14 \\
\hline \multirow{10}{*}{ 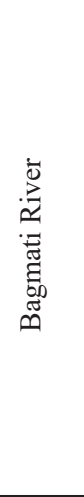 } & BW18(US) & 4.53 & 9.29 & 15 & 25 & 42.00 & 0.59 \\
\hline & BW18(DS) & 4.59 & 16.75 & 21286 & 21303 & 42.12 & 505.77 \\
\hline & BW16(US) & 8.33 & 6.33 & 162 & 168 & 52.62 & 3.19 \\
\hline & BW16(DS) & 8.40 & 3.18 & 155 & 158 & 52.70 & 3.00 \\
\hline & BW19(US) & 9.50 & 5.73 & 140 & 146 & 59.90 & 2.44 \\
\hline & BW19(DS) & 9.58 & 15.53 & 43124 & 43140 & 60.70 & 710.70 \\
\hline & BW12(US) & 10.65 & 5.71 & 1230 & 1236 & 69.70 & 17.73 \\
\hline & BW12(DS) & 10.68 & 3.41 & 1859 & 1862 & 69.90 & 26.64 \\
\hline & BW7(US) & 14.15 & 3.45 & 265 & 268 & 73.65 & 3.65 \\
\hline & BW7(DS) & 14.21 & 7.10 & 14231 & 14238 & 74.20 & 191.89 \\
\hline \multirow{10}{*}{$\begin{array}{l}\frac{\pi}{0} \\
\overline{0} \\
\underline{0} \\
0 \\
0 \\
0 \\
0\end{array}$} & DW27(US) & 3.03 & 521.02 & 197 & 718 & 10.60 & 67.73 \\
\hline & DW27(DS) & 3.12 & 235.51 & 162 & 397 & 10.76 & 36.91 \\
\hline & DW22(US) & 4.61 & 609.88 & 3210 & 3820 & 17.46 & 218.77 \\
\hline & DW22(DS) & 4.72 & 134.07 & 44071 & 44205 & 17.73 & 2493.22 \\
\hline & DW14(US) & 6.34 & 82.38 & 1923 & 2005 & 19.13 & 104.81 \\
\hline & DW14(DS) & 6.45 & 97.57 & 39 & 137 & 19.27 & 7.10 \\
\hline & DW9(US) & 7.59 & 39.65 & 440 & 480 & 23.37 & 20.52 \\
\hline & DW9(DS) & 7.69 & 51.13 & 168 & 219 & 23.48 & 9.32 \\
\hline & DW2(US) & 11.75 & 14.04 & 6 & 20 & 28.78 & 0.70 \\
\hline & DW2(DS) & 11.9 & 15.23 & 6094 & 6109 & 29.26 & 208.79 \\
\hline \multirow{10}{*}{ 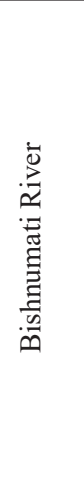 } & BMW33(US) & 11.13 & 36.55 & 459 & 496 & 14.00 & 35.40 \\
\hline & BMW33(DS) & 11.23 & 64.80 & 31843 & 31908 & 14.05 & 2271.01 \\
\hline & BMW28(US) & 13.58 & 25.03 & 697 & 722 & 37.05 & 19.48 \\
\hline & BMW28(DS) & 13.70 & 55.61 & 40203 & 40259 & 37.23 & 1081.36 \\
\hline & BMW23(US) & 21.23 & 94.51 & 115 & 209 & 63.23 & 3.31 \\
\hline & BMW23(DS) & 21.33 & 156.10 & 5669 & 5825 & 63.42 & 91.85 \\
\hline & BMW18(US) & 24.05 & 37.15 & 78 & 115 & 71.22 & 1.62 \\
\hline & BMW18(DS) & 24.20 & 31.24 & 253 & 284 & 71.34 & 3.99 \\
\hline & BMW9(US) & 26.68 & 28.77 & 23 & 52 & 89.34 & 0.58 \\
\hline & BMW9(DS) & 26.80 & 26.14 & 11032 & 11058 & 90.64 & 122.00 \\
\hline
\end{tabular}


Dry season discharge and sediment yield of the northern tributaries of the Kathmandu Valley, Central Nepal

Table 4: Discharge and stream powers of the northern rivers in the Kathmandu Valley

\begin{tabular}{|c|c|c|c|c|c|c|c|c|c|}
\hline River & Location & $\begin{array}{c}\text { Distance } \\
(\mathrm{km})\end{array}$ & $\begin{array}{c}\tau_{\mathrm{b}} \\
\left(\mathrm{KN} / \mathrm{m}^{2}\right)\end{array}$ & Area $\left(m^{2}\right)$ & $\begin{array}{c}\mathrm{V} \\
(\mathrm{m} / \mathrm{s})\end{array}$ & $\begin{array}{l}\text { Total discharge } \\
\left(\mathrm{m}^{3} / \mathrm{s}\right)\end{array}$ & $\begin{array}{l}\text { Slope } \\
(\mathrm{m} / \mathrm{m})\end{array}$ & $\begin{array}{c}\Omega=\gamma \mathrm{QS} \\
(\mathrm{KN} / \mathrm{s} / \mathrm{m})\end{array}$ & $\begin{array}{c}\omega=\tau_{\mathrm{b}^{*}} \mathrm{~V} \\
\left(\mathrm{KN} / \mathrm{ms} / \mathrm{m}^{2}\right)\end{array}$ \\
\hline \multirow{10}{*}{ 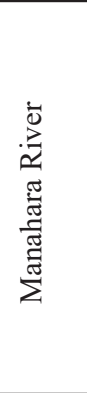 } & MW25(US) & 1.20 & 0.016 & 0.18 & 0.32 & 0.060 & 0.022 & 0.013 & 0.005 \\
\hline & MW25(DS) & 1.30 & 0.201 & 0.23 & 0.30 & 0.059 & 0.240 & 0.139 & 0.060 \\
\hline & MW28(US) & 8.54 & 0.005 & 0.74 & 0.27 & 0.193 & 0.003 & 0.007 & 0.001 \\
\hline & MW28(DS) & 8.61 & 0.037 & 0.54 & 0.36 & 0.204 & 0.040 & 0.080 & 0.013 \\
\hline & MW22(US) & 13.16 & 0.006 & 1.10 & 0.63 & 0.711 & 0.004 & 0.030 & 0.004 \\
\hline & MW22(DS) & 13.23 & 0.070 & 1.29 & 0.35 & 0.443 & 0.043 & 0.186 & 0.024 \\
\hline & MW16(US) & 17.69 & 0.003 & 1.03 & 0.27 & 0.286 & 0.002 & 0.005 & 0.001 \\
\hline & MW16(DS) & 17.76 & 0.020 & 0.90 & 0.30 & 0.293 & 0.013 & 0.038 & 0.006 \\
\hline & MW9(US) & 19.71 & 0.013 & 0.89 & 0.48 & 0.481 & 0.008 & 0.038 & 0.006 \\
\hline & MW9(DS) & 19.74 & 0.092 & 1.71 & 0.41 & 0.717 & 0.033 & 0.234 & 0.038 \\
\hline \multirow{10}{*}{ 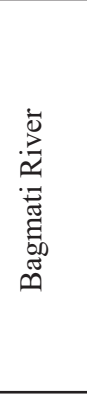 } & BW18(US) & 4.53 & 0.002 & 1.03 & 0.33 & 0.386 & 0.002 & 0.008 & 0.001 \\
\hline & BW18(DS) & 4.59 & 0.030 & 2.16 & 0.12 & 0.294 & 0.010 & 0.029 & 0.004 \\
\hline & BW16(US) & 8.33 & 0.002 & 1.58 & 0.37 & 0.628 & 0.001 & 0.006 & 0.001 \\
\hline & BW16(DS) & 8.40 & 0.015 & 1.13 & 0.43 & 0.571 & 0.008 & 0.045 & 0.007 \\
\hline & BW19(US) & 9.50 & 0.003 & 1.48 & 0.22 & 0.422 & 0.002 & 0.008 & 0.001 \\
\hline & BW19(DS) & 9.58 & 0.047 & 1.22 & 0.32 & 0.473 & 0.020 & 0.093 & 0.015 \\
\hline & BW12(US) & 10.65 & 0.008 & 2.44 & 0.30 & 0.756 & 0.004 & 0.030 & 0.002 \\
\hline & BW12(DS) & 10.68 & 0.024 & 2.06 & 0.50 & 1.076 & 0.013 & 0.137 & 0.012 \\
\hline & BW7(US) & 14.15 & 0.002 & 6.00 & 0.28 & 1.703 & 0.001 & 0.017 & 0.001 \\
\hline & BW7(DS) & 14.21 & 0.014 & 5.52 & 0.33 & 1.983 & 0.008 & 0.156 & 0.005 \\
\hline \multirow{10}{*}{$\begin{array}{l}\frac{\pi}{0} \\
\frac{1}{1} \\
0 \\
0 \\
0 \\
0\end{array}$} & DW27(US) & 3.03 & 0.016 & 0.09 & 0.34 & 0.033 & 0.023 & 0.007 & 0.005 \\
\hline & DW27(DS) & 3.12 & 0.012 & 0.18 & 0.32 & 0.062 & 0.011 & 0.007 & 0.004 \\
\hline & DW22(US) & 4.61 & 0.011 & 0.36 & 0.23 & 0.085 & 0.008 & 0.007 & 0.003 \\
\hline & DW22(DS) & 4.72 & 0.030 & 0.32 & 0.25 & 0.087 & 0.027 & 0.023 & 0.008 \\
\hline & DW14(US) & 6.34 & 0.022 & 0.37 & 0.18 & 0.086 & 0.015 & 0.013 & 0.004 \\
\hline & DW14(DS) & 6.45 & 0.009 & 0.27 & 0.43 & 0.116 & 0.009 & 0.010 & 0.004 \\
\hline & DW9(US) & 7.59 & 0.007 & 0.98 & 0.28 & 0.292 & 0.005 & 0.014 & 0.002 \\
\hline & DW9(DS) & 7.69 & 0.007 & 0.19 & 0.27 & 0.245 & 0.020 & 0.048 & 0.002 \\
\hline & DW2(US) & 11.75 & 0.002 & 2.29 & 0.53 & 1.458 & 0.001 & 0.021 & 0.001 \\
\hline & DW2(DS) & 11.9 & 0.045 & 1.44 & 0.46 & 1.974 & 0.027 & 0.516 & 0.020 \\
\hline \multirow{10}{*}{ 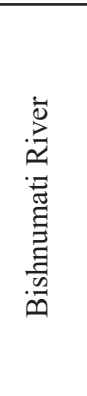 } & BMW33(US) & 11.13 & 0.015 & 0.30 & 0.30 & 0.104 & 0.018 & 0.018 & 0.005 \\
\hline & BMW33(DS) & 11.23 & 0.040 & 0.50 & 0.23 & 0.116 & 0.035 & 0.039 & 0.009 \\
\hline & BMW28(US) & 13.58 & 0.006 & 1.30 & 0.25 & 0.359 & 0.003 & 0.011 & 0.002 \\
\hline & BMW28(DS) & 13.70 & 0.043 & 1.99 & 0.19 & 0.376 & 0.013 & 0.049 & 0.008 \\
\hline & BMW23(US) & 21.23 & 0.002 & 1.66 & 0.30 & 0.522 & 0.001 & 0.005 & 0.001 \\
\hline & BMW23(DS) & 21.33 & 0.024 & 0.98 & 0.47 & 0.507 & 0.013 & 0.066 & 0.011 \\
\hline & BMW18(US) & 24.05 & 0.003 & 2.42 & 0.36 & 1.007 & 0.001 & 0.009 & 0.001 \\
\hline & BMW18(DS) & 24.20 & 0.005 & 3.19 & 0.24 & 0.932 & 0.001 & 0.010 & 0.001 \\
\hline & BMW9(US) & 26.68 & 0.004 & 4.99 & 0.33 & 1.715 & 0.001 & 0.010 & 0.001 \\
\hline & BMW9(DS) & 26.80 & 0.023 & 1.75 & 0.62 & 1.256 & 0.008 & 0.092 & 0.014 \\
\hline
\end{tabular}

of bed area. The stream power per unit of bed area is shown in the Table 4 for major tributaries of the Bagmati River in the northern part. The stream power ranged from 0.001 to $0.060 \mathrm{KN} / \mathrm{ms} / \mathrm{m}^{2}$ in the Manahara River, 0.001 to $0.15 \mathrm{KN} / \mathrm{ms} / \mathrm{m}^{2}$ in the Bagmati River, 0.001 to $0.020 \mathrm{KN} / \mathrm{ms} / \mathrm{m}^{2}$ in the Dhobi Khola and 0.001 to $0.014 \mathrm{KN} / \mathrm{ms} / \mathrm{m}^{2}$ in the Bishnumati River. The stream power was very high at MW25(DS) of the Manahara
River, and its linear trend was continuously decreasing towards downstream (Fig. 5). The Bagmati and the Bishnumati Rivers had stream power almost constant throughout studied transects. However, in case of the Dhobi Khola, it was gradually increasing towards downstream. 

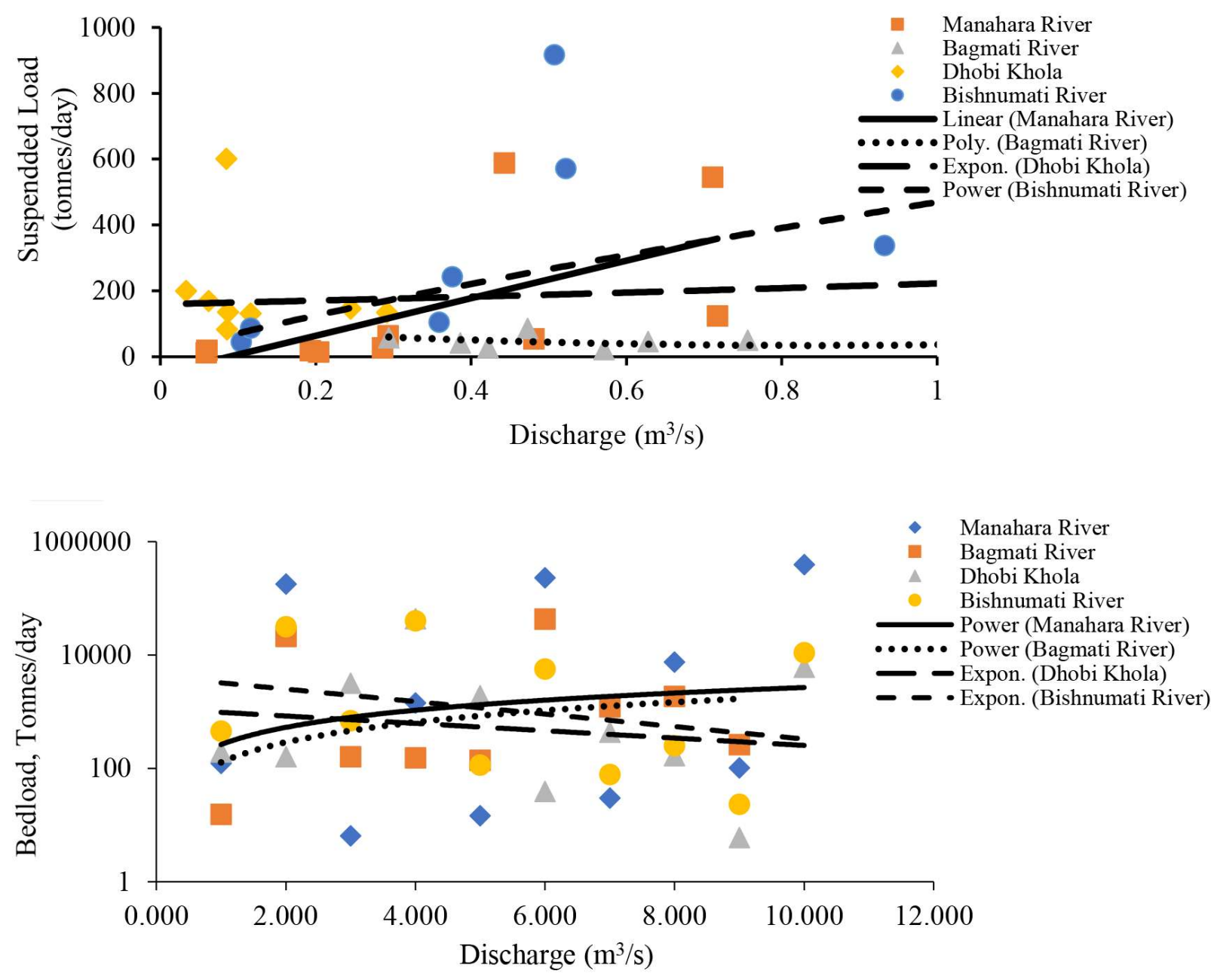

Fig. 4 Sediment rating curves: (a) Sediment load and (b) bed load for different rivers

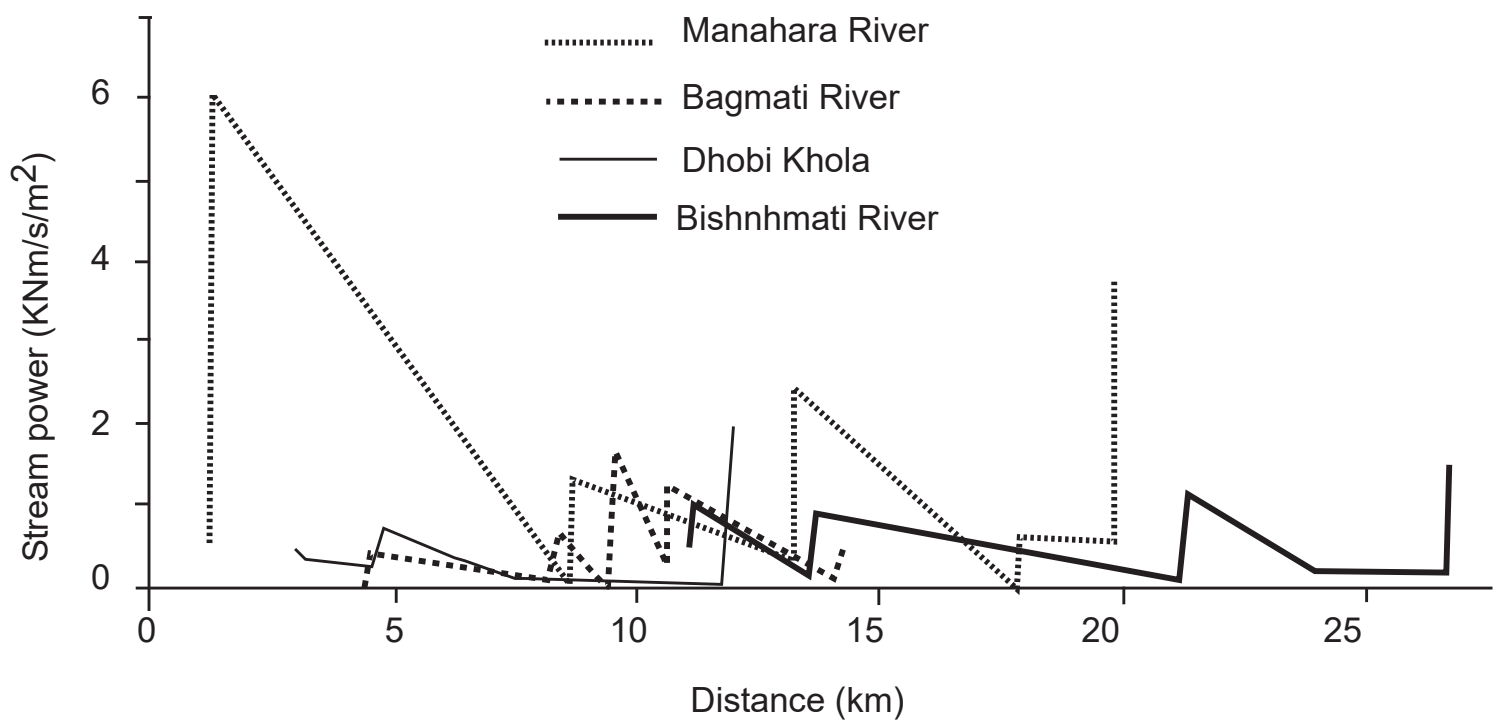

Fig. 5 Trends of stream power of different rivers in the northern Kathmandu Valley 
Table 5: Shear velocity, particle Reynolds number, shear stresses and dimensionless shear stresses

\begin{tabular}{|c|c|c|c|c|c|c|c|c|c|c|c|c|c|c|c|}
\hline 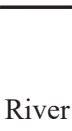 & Location & $\begin{array}{c}\text { Distance } \\
(\mathrm{km})\end{array}$ & $\begin{array}{l}\text { Water } \\
\text { temp }\end{array}$ & ${ }_{0}, \mathrm{~m}$ & & $\mathrm{R}_{\mathrm{h}}, \mathrm{m}$ & $\mathrm{S}, \mathrm{m} / \mathrm{m}$ & $\begin{array}{c}\tau_{\mathrm{b}}, \\
\mathrm{KN} / \mathrm{m}^{2}\end{array}$ & $\tau_{\mathrm{b}}{ }^{*}$ & $\begin{array}{c}\mu, .10^{-6} \\
\mathrm{~m}^{2} / \mathrm{s}\end{array}$ & $\begin{array}{c}\rho, \\
\mathrm{Kg} / \mathrm{m}^{3}\end{array}$ & $\begin{array}{c}U^{*}= \\
\left(\tau_{\mathrm{b}} / \rho\right)^{0.5} \\
\mathrm{~m} / \mathrm{s}\end{array}$ & $\begin{array}{r}\mathrm{R}_{\mathrm{ep}} \\
\left(\mathrm{U} * \mathrm{~d}_{5}\right.\end{array}$ & $=\tau_{\mathrm{c}}{ }^{*}$ & $\tau * / \tau_{c}{ }_{b}$ \\
\hline \multirow{10}{*}{ 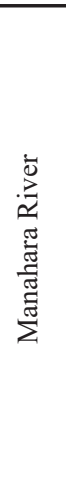 } & MW25(US) & 120 & 27.20 & 0.012 & 9.777 & 0.07 & 0.022 & 0.045 & 0.2254 & 0.893 & 995.7 & 0.212 & 2845 & 0.060 & 3.76 \\
\hline & MW25(DS) & 120 & & & & & & & & & & 734 & & & 108.44 \\
\hline & MW28(US) & & 8.90 & 022 & & & & 0.013 & 8 & & & 0.116 & 3186 & & 0.61 \\
\hline & 1W28(DS) & 61 & 3.90 & 0.020 & 9.765 & & & 0.109 & 0.3315 & 0.800 & 995.7 & 0.331 & 8286 & 0.053 & 6.25 \\
\hline & MW22(US) & 3.16 & 30.50 & 0.025 & 0765 & 0.13 & 0.004 & 0.017 & 0.0422 & 0.800 & 995.7 & 0.132 & 4132 & 0.060 & 0.70 \\
\hline & MW22(DS) & 23 & 30.00 & 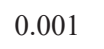 & & 0.7 & 0043 & 0.214 & & 0.800 & 995.7 & 0.463 & 463 & 0.060 & 209.00 \\
\hline & MW16(US) & 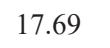 & 30.00 & 0.002 & & & & 0.009 & & 0.800 & 995.7 & 0.094 & 199 & 0.060 & 5.19 \\
\hline & MW16(DS) & 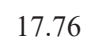 & 29.50 & 0.001 & & & 0.013 & 0.060 & & 800 & 995.7 & 0.245 & 245 & 0.060 & 75.48 \\
\hline & MW & 19.71 & 26.50 & 0. & 9 & & 008 & 0 & & 393 & 995.7 & 0.186 & 3759 & & 1.94 \\
\hline & MW9(DS) & 19.74 & 25.10 & 0.001 & 9.777 & 0.28 & 0.033 & 0.237 & 20.531 & 0.893 & 995.7 & 0.488 & 383 & 0.060 & 342.18 \\
\hline \multirow{10}{*}{ 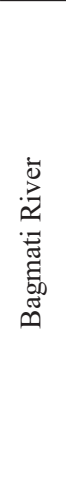 } & BW18(US) & 452 & 22.40 & & & 012 & 0002 & 0006 & & 1.003 & 998.2 & 0.075 & 224 & & 2.17 \\
\hline & BW18(DS) & 50 & 22.90 & & & & & 0.069 & & 893 & 998.2 & 0.263 & 265 & 0.042 & 110.69 \\
\hline & BW16(US) & 8.33 & 22.90 & 0002 & 9.789 & & 0.001 & 0.006 & 1.6799 & 893 & 998.2 & 0.075 & 17 & 0.032 & 52.50 \\
\hline & BW16(DS) & 8.40 & 22.70 & 0200 & 9.789 & 0.20 & 0.008 & 0.036 & 0.1086 & 893 & 998.2 & 0.189 & 4244 & 0.060 & 1.81 \\
\hline & BW19(US) & 9.50 & 24.50 & 0006 & 9.777 & 0.14 & 0.002 & 0.007 & 0.7291 & 0.893 & 998.2 & 0.084 & 54 & & 19.19 \\
\hline & BW19(DS) & 9.58 & 24.70 & & & & & & & & & 0.346 & & & 129.3 \\
\hline & BW12(US) & 10.65 & 22.60 & 0.0010 & 9.789 & 0.20 & 0.004 & 0.018 & 1.0775 & 0.893 & 998.2 & 0.133 & 149 & 0.050 & 21.55 \\
\hline & & 10.68 & 23.10 & & & & 013 & 0.057 & & 893 & 998.2 & 0.239 & 2671 & 0.060 & 5.74 \\
\hline & BW7(US) & 14.15 & 24.80 & 0005 & 9.777 & .24 & .001 & 0.006 & 7362 & 893 & 998.2 & 0.078 & 44 & 0.032 & 23.01 \\
\hline & BW7(DS) & 14.21 & 25.00 & 0.0010 & 9.777 & 0.18 & 0.008 & 0.036 & 2.2033 & 893 & 998.2 & 0.191 & 214 & 0.050 & 44.07 \\
\hline \multirow{10}{*}{$\begin{array}{l}\frac{\pi}{8} \\
\frac{1}{1} \\
\ddot{0} \\
0 \\
0\end{array}$} & & 3.03 & 30.90 & & & & & & & & & 0.225 & 983 & & 1452 \\
\hline & & & & & & & & & & & & & & & $4 . / 1$ \\
\hline & DW22(US) & 01 & 32.00 & 0002 & & & .008 & 0.038 & & 800 & 995.7 & 0.194 & 46 & 0.050 & 239.83 \\
\hline & DW22(DS) & 4.72 & 29.90 & .0002 & 9.765 & 11 & 027 & 0.092 & 30.8699 & 800 & 995.7 & 0.303 & 68 & 0.053 & 582.45 \\
\hline & DW14(US) & 6.34 & 29.70 & 0.0016 & 9.765 & 0.15 & 0.015 & 0.067 & 2.5248 & 0.800 & 995.7 & 0.259 & 517 & 0.060 & 42.08 \\
\hline & DW14(DS) & 615 & 29.50 & 0.0100 & & & 0.009 & & & & 995.7 & 0.169 & 2117 & & \\
\hline & DW9(US) & & & & & & & & & & & & & & \\
\hline & & & & & & & & & & & & 0.140 & & & \\
\hline & & & 26.40 & & & & & & & & & 082 & 193 & & 0.52 \\
\hline & DW2(DS) & 11.9 & 27.50 & 0.0110 & 9.765 & 0.17 & 0.027 & 0.126 & 0.6960 & 0.893 & 995.7 & 0.356 & 4387 & 0.060 & 11.60 \\
\hline \multirow{10}{*}{ 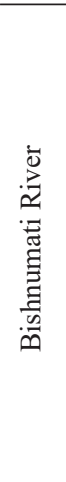 } & & 11.13 & 20.80 & & & & & & & & & 0.181 & & & \\
\hline & BMW33(DS) & 11.23 & 23.50 & & & & & & & & & & 278 & 0.060 & \\
\hline & & & & & & & 0.003 & & & 0.893 & 998.2 & 0.122 & 68 & 0.040 & 45.02 \\
\hline & BMW28(DS) & 13.70 & 25.10 & 0.0010 & $9.7^{\prime}$ & 0.33 & 0.013 & 0.111 & 555 & 0.893 & 995.7 & 0.335 & 375 & 0.058 & 116.4 \\
\hline & BMW23(US) & 21.23 & 26.50 & 0002 & 9 & & 1 & 0.005 & & & 995.7 & 0.072 & 16 & 0.045 & 35.07 \\
\hline & BMW23(DS) & 21.33 & 26.30 & & & & & & & & & 0.253 & 425 & 0.055 & 46.82 \\
\hline & BMW18(US) & 24.05 & 27.80 & 0.0009 & 9.765 & 0.36 & 0.001 & 0.009 & 0.6200 & 0.800 & 995.7 & 0.096 & 108 & 0.040 & 15.50 \\
\hline & BMW18(DS) & 24.20 & 28.40 & 0.0009 & 9.765 & 0.48 & 0.001 & 0.016 & 1.0580 & 0.800 & 995.7 & 0.126 & 141 & 0.060 & 17.63 \\
\hline & BMW9(US) & 26.68 & 28.50 & 0.0040 & & .63 & 0.001 & 0.010 & 0.1559 & 0.800 & 995.7 & 0.102 & 508 & 0.060 & 2.60 \\
\hline & BMW9(DS) & 26.80 & 28.90 & 0.0007 & 9.765 & 0.32 & 0.008 & 0.069 & 5.9396 & 0.800 & 995.7 & 0.262 & 230 & 0.052 & 114.22 \\
\hline
\end{tabular}




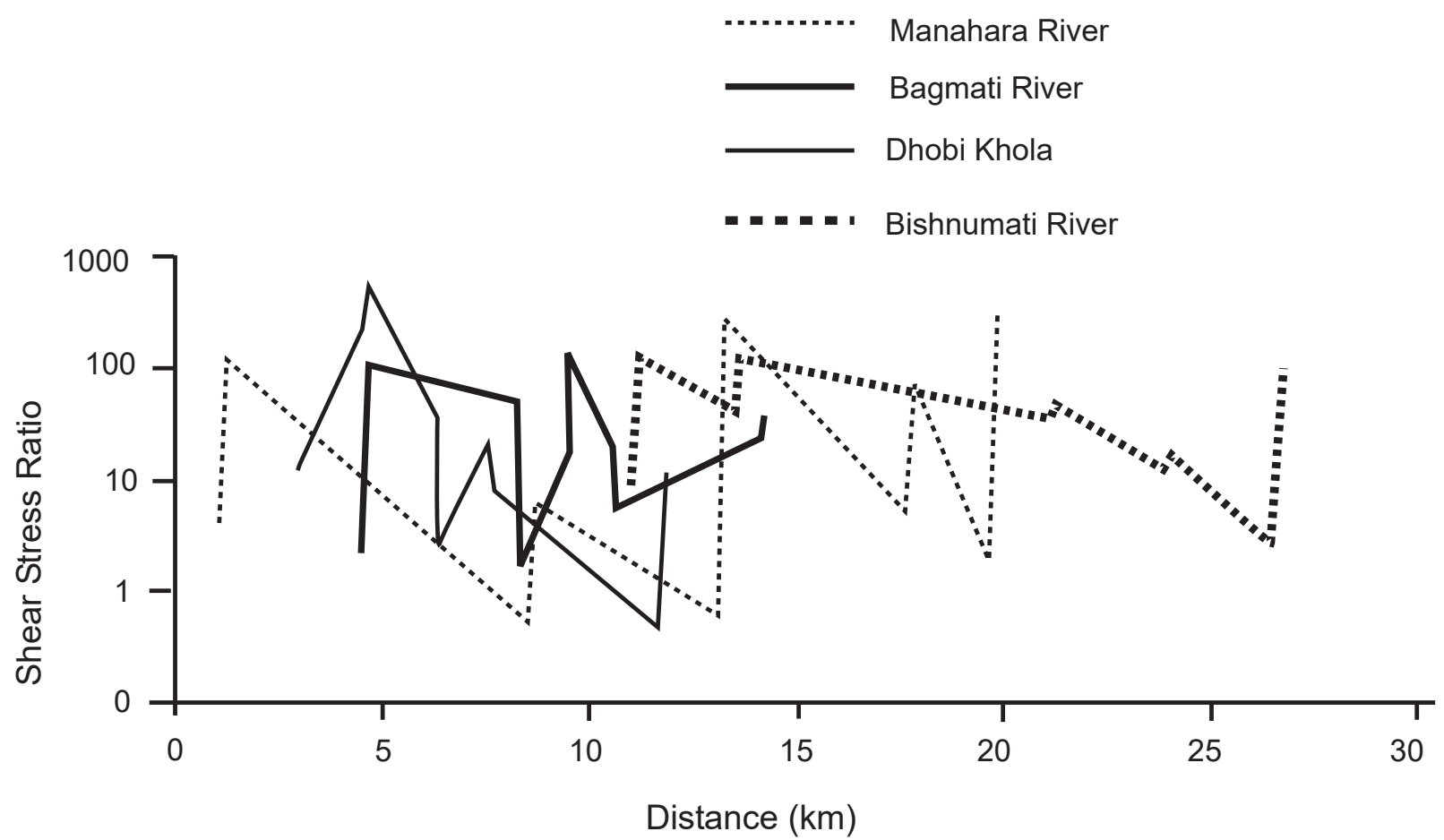

Fig. 6 Variation of the shear stress ratio of different rivers in the northern Kathmandu Valley

\section{Stream competence}

Stream competence evaluation in the main tributaries of the Bagmati River in the northern part was evaluated with boundary shear stress and critical boundary stress ratio in each transects of the rivers. The shear stress ratio of all the transects of the Bagmati River was higher than 1 (Table 5). It referred to that the studied transects have erosivity which was competent to erode sediments from the stream transects. The shear stress ratio gradually increased towards the downstream (Fig. 6) although the trends are fluctuating. The same trend was followed by the Bishnumati River and other streams, however, the shear stress ratio gradually diminished towards downstreams. Two transects MW28(US) and MW22(US) of the Manahara River and transect DW2(US) of the Dhobi Khola had the shear stress ratios less than unity and showed their incompetency.

\section{CONCLUSIONS}

The Bagmati River basin is non-glacial river basin, in which discharge mainly is dependent upon rain fall. The Bagmati River basin in the northern Kathmandu
Valley consists of four main tributaries the Manahara River, Bagmati River, the Dhobi Khola and the Bishnumati River. The four major tributaries including the Bagmati River were upto sixth stream order. Fluvial geomorphology of the Bagmati River in its northern part is influenced by the mass wasting, flooding, bank erosion, sediment erosion, transport and deposition, and vegetation growth phenomena as well as the dominant anthropogenic activities. Increasing population and changing in land use pattern have affected the stream discharge and sediment transport capacity of the river that ultimately has influenced the river sediment dynamics.

The study revealed that the water discharge was varying from location to location and river to river. The minimum water discharge was $0.033 \mathrm{~m}^{3} / \mathrm{s}$ at Tankal of the Dhobi Khola and maximum $\left(1.983 \mathrm{~m}^{3} / \mathrm{s}\right)$ at Sankhamul of the Bagmati river. The lowest median grain size distribution $\left(\mathrm{d}_{50}\right)$ was $0.0002 \mathrm{~m}$ at Gokarneshor Temple area of the Bagmati River and the highest was $0.0250 \mathrm{~m}$ at Changunarayan of the Manahara River. The study found that suspended load for dry season varied from the 916 (Naya bus park area) to $12 \mathrm{mg} / \mathrm{L}$ (Sankhu of the Manahara River) and bed 
load 6 Tonnes/day (Sankhu and Salmutar) to 393711 Tonnes/day (Narephat of the Manahara River). The total sediment yield was ranging from 0.53 (Sankhu, Salmutar of the Manahara River) to 22029.64 Tonnes $/ \mathrm{km}^{2} /$ day (Sankhu of the Manahara River). The boundary shear stress and the critical shear stress were ranging from 0.0312 to $30.87 \mathrm{~N} / \mathrm{m}^{2}$ and $0.032 \mathrm{~N} / \mathrm{m}^{2}$ to $0.06 \mathrm{~N} / \mathrm{m}^{2}$, respectively. The stream power was found to range from 0.001 to $0.06 \mathrm{KNm} / \mathrm{s} / \mathrm{m}^{2}$. The study was carried out during the dry season therefore the results only represent the outcomes for the dry period only, and the study helps to proper engineering hydraulic practices around the tributaries corridor.

Some sites for instance, Salmutar (Sankhu) and Changunarayan of the Manahara River had more erodibility. Such sites need river training to protect from the scouring of river during particular season. Thus, spotted sensitive area which is highly erodible; Bhuddhanagar of the Dhobi Khola, Dalanepul of the Dhobi Khola, Nayabasti (Jorpati), Tinkune (Gairigaun) of the Bagmati River should be channel improved using favorable techniques such as gabion wall construction, riprap, etc.

Sand mining and quarry at channel and bank areas reduced the stability of area and supported the channel shifting. Therefore, mining should be done in a scientific way. Year-wise monitoring of rivers by installing the river gauge stations in the channel in different locations should be done to study the anthropogenic influence on the stream characteristics.

\section{ACKNOWLEDGEMENTS}

Authors are thankful to M. Shrestha and B. Phuyal for field assistance. Authors are also thankful to the Central Department of Geology for providing necessary field equipments and lab facilities.

\section{REFERENCES}

Ashmore, P.E. and Day, T.J., 1988, Spatial and temporal patterns of suspended sediment yield in the Saskatchewan River basin. Canadian Journal of Earth Science, v. 25, pp. 1450-1463.

ASTM D3977-97, 2002, Standard test Methods for Determining Sediment Concentration in Water Samples, ASTM International, West Conshohocken.
Bunte, K. and Abt, S. R., 2001. Sampling Surface and Subsurface Particle-Size Distributions in Wadable Graveland Cobble-Bed Streams for Analyses in Sediment Transport, Hydraulics, and Streambed Monitoring. United States Department of Agriculture Forest Service Rocky Mountain Research Station, General Technical Report RMRS-GTR-74, 428p.

DMG (Department of Mining and geology), 1998. Engineering and Environmental Geological Map of Kathmandu Valley, Department of Mines and Geology, Lainchaur, Kathmandu.

Guzman, C. D., Tilahun, S. A., Zegeye, A. D. and Steenhuis, T. A., 2013. Suspended sediment concentration-discharge relationship in the subhumid Ethiopian Highlands.Hydrology and Earth System Sciences, pp. 1067-1077.

Hassanzadeh, Y., 2007. Evaluation of Sediments Load in a Natural River. Journal of Water International, v. 32(1), pp. $145-154$.

Powell, D. M., Reid, I., Laronne, J. B. and Frostick, L. E., 1996. Bedload as a component of sediment yield from a semiarid watershed of the northern Negev. In: Proceedings of the Symposium on Erosion and Sediment Yield: Global and Regional Perspectives. International Association of Hydrology Science, Exter, v. 236, pp.389-397.

Rosgen, D.L., 1994, A classification of natural rivers, Cantenna, v. 22, pp. 169-199.

Shrestha, P. and Tamrakar, N.K., 2007 a. Streambankerodability and lateral instability hazard in the Manahara River, Kathmandu Basin, Nepal. Journal of Nepal Geological Society, v. 35, pp. 55-66.

Shrestha, P. and Tamrakar, N.K., 2007b. Bank erosion and bank material loss potential in Manahara River, Kathmandu, Nepal. Bulletin of Department of Geology, Tribhuvan University, Kathmandu, Nepal, v. 10, pp. 33-44.

Stöcklin, J., 1980. Geology of Nepal and its regional frame. Jour. Geol. Soc. London, v. 137, pp. 1-34. http://dx.doi.org/10.1144/gsjgs.137.1.0001

Stöcklin, J. and Bhattarai, K.D., 1977. Geology of the Kathmandu area and Central Mahabharat range, Nepal Himalaya. Report of Department of Mines and Geology/ UNDP (unpublished report), 86p.

Tamrakar, N.K., 2004a. River degradation problems along the Bishnumati River corridor in the Kathmandu Basin. A report submitted to Human and Geoscience Group, $37 \mathrm{p}$.

Tamrakar, N.K., 2004b. Disturbances and instabilities in the Bishnumati River corridor, Kathmandu basin, JUSAN, v. 9(16), pp. 7-18. 
Tamrakar, N.K., 2009. Riverbed-material texture and composition of Bishnumati River, Kathmandu, Nepal; implication in provenance analysis. Bulletin of the Department of Geology, Tribhuvan University, Kathmandu, Nepal, v. 12, pp. 55-62.

Tamrakar, N.K. and Shrestha, M.B., 2008. Relationship between fluvial clastic sediment and source rock abundance in Rapti River Basin of Central Nepal Himalaya. Boletin de Geologia, v. 30, no. 1, pp. 63-75.

Tamrakar, N.K., Bajracharya, R. and Shrestha, P., 2011. River dynamics and existing stability condition of the Manahara River, Kathmandu basin, Central Nepal Himalaya. Bull. Dept. Geol., v. 14, pp. 1-8.

UNICEF 2008. Handbook on Water Quality, UN Plaza, New York, $160 \mathrm{p}$.

Wolman, M. G. and Miller, J. P., 1960. Magnitude and frequency of forces in geomorphic processes.Journal of Geology, v. 68, pp. 54-74.

Yoshida, M. and Igarashi, Y., 1984. Neogene to quaternary lacustrine sediments in the Kathmandu Valley, Nepal, Journal of Nepal Geological Society, v. 4, pp. 73-100. 